\title{
Pelatihan penggunaan media sosial sebagai sarana dakwah bagi penyuluh agama islam di masa pandemi
}

\author{
Adityo Permana Wibowo 1,*, Donny Avianto ${ }^{2}$, Arief Hermawan ${ }^{3}$ \\ ${ }^{1,2}$ Program Studi Informatika, Fakultas Teknologi Informasi dan Elektro \\ ${ }^{3}$ Program Magister Teknologi Informasi \\ Universitas Teknologi Yogyakarta \\ Email Korespondensi: *adityopw@uty.ac.id
}

Received December 12, 2020; Revised February 2, 2021; Accepted February 5, 2021

\begin{abstract}
Abstrak
Masa pandemi Covid-19 menghentikan semua aktivitas yang mengundang keramaian, salah satunya adalah kegiatan kajian agama islam baik itu dalam bentuk pertemuan klasikal sampai dengan tabligh akbar. Sementara penyuluh Agama Islam dituntut untuk tetap produktif. Kementerian Agama Kab. Sleman membuat kebijakan bahwa seluruh penyuluh agama di bawah Kementerian Kab. Sleman harus tetap produktif dalam memberikan penyuluhan Agama Islam kepada Masyarakat. Salah satu cara penyuluhan yang digunakan adalah memanfaatkan media sosial, yaitu YouTube. Permasalahannya adalah tidak semua penyuluh agama di Kab. Sleman familiar dengan YouTube, sehingga diperlukan adanya pelatihan dalam penggunaan media sosial YouTube sebagai sarana dakwah. Kegiatan dilakukan dalam bentuk pelatihan dan pendampingan dalam menggunakan YouTube bagi penyuluh agama dalam mulai dari create account, upload video, pengaturan dan pemberian deskripsi video, sampai dengan pendaftaran monetisasi YouTube. Berdasarkan hasil kuesioner, pelatihan dan pendampingan ini sukses membantu para penyuluh agama tetap produktif dalam menyampaikan dakwahnya melalui video yang diunggah di YouTube dengan tingkat kesuksesan di atas 85\%. Selain itu video dakwah yang diunggah bisa memenuhi syarat dan ketentuan untuk didaftarkan monetisasi.
\end{abstract}

Kata Kunci: Pelatihan; Media Sosial; Penyuluh Agama; Pandemi Covid-19

\section{Abstract}

The period of the Covid-19 pandemic stopped all activities that invited crowds, one of which was Islamic study activities, both in the form of classical meetings to tabligh akbar. Meanwhile, Islamic religious extension workers are required to remain productive in providing da'wah to the community. Ministry of Religion Kab. Sleman made a policy that all religious extension workers under the Ministry of Kab. Sleman must remain productive. One method of da'wah used is to use social media, namely YouTube. The problem is that not all religious extension agents in Kab. Sleman is familiar with YouTube, so training is needed in the use of YouTube as a means of preaching. Activities are carried out in the form of training and assistance in using YouTube for religious instructors, starting from creating accounts, uploading videos, arranging and providing video descriptions, to registering for YouTube monetization. Based on the questionnaire result, this training and assistance were successful in helping religious extension agents to remain productive in conveying their da'wah through videos uploaded on YouTube with a success rate of over 85\%. In addition, the da'wah video that is uploaded can be eligible for monetization registration

Keywords : Training; Social media; Religious Counselor; The Covid-19 pandemic

\section{PENDAHULUAN}

Terhitung sejak bulan Maret 2020, WHO menetapkan kondisi Pandemic Covid-19 [1]. Bulan Maret 2020 dilaporkan kasus pertama pasien positif Covid-19 di Indonesia, dan sampai dengan November 2020 kasus tersebut semakin bertambah [2]. Untuk mencegah penyebaran Virus Corona, pemerintah Indonesia membuat beberapa kebijakan diantaranya membatasi aktivitas kegiatan diluar rumah, sekolah dari rumah, bekerja dari rumah, sampai kegiatan keagamaan untuk dilakukan di rumah [3]. Pemerintah melarang diadakan acara yang mengundang kerumunan warga. Banyak profesi yang terdampak dari kondisi Pandemi Covid-19 salah satunya adalah profesi pengajar yang biasa melakukan sharing Knowledge dan membutuhkan audience sebagai peserta dari suatu kegiatan. Penyuluh Agama Islam merupakan salah satu profesi yang bisa 
mengundang keramaian, karena mengundang audience atau jamaah sebagai pesertanya. Penyuluh Agama Islam di Kab. Sleman dikoordir oleh Kementerian Agama Kabupaten Sleman.

Adanya kebijakan pemerintah terkait pembatasan keramaian, membuat penyuluh Agama Islam tidak bisa mengadakan penyuluhan agama dalam bentuk pertemuan klasikal apalagi Tabligh Akbar. Melihat kondisi yang demikian, Kementerian Agama pusat memberikan instruksi kepada Kementerian Agama Kabupaten Sleman untuk membuat sebuah terobosan agar penyuluh agama tetap melakukan ativitasnya memberikan penyuluhan agama kepada warga masyarakat. Selanjutnya Kementerian Agama Kab. Sleman membuat kebijakan bagi penyuluh Agama Islam untuk menggunakan media sosial dalam hal ini YouTube untuk melakukan penyuluhan agama secara online, sehingga diharapkan penyuluh agama di bawah Kementerian Kab. Sleman tetap produktif dalam memberikan penyuluhan Agama Islam kepada Masyarakat.

Penggunaan YouTube sebagai media pembelajaran sudah banyak dilakukan [4] [5], salah satunya sebagai media pembelajaran Bahasa Indonesia dan ternyata juga mempunyai efek positif terhadap efektivitas pembelajaran bagi peserta didiknya [6][7]. Selain media pembelajaran, YouTube juga bsia digunakan sebagai media marketing yang bisa mempengaruhi minat beli dan loyalitas [8].

Bulan Januari 2019, pengguna internet di Indonesia sebanyak 150 juta terjadi penambahan sekitar $13 \%$ dari tahun 2018 [9]. Kemudian pada bulan Januari 2020, pengguna internet di Indonesia mengalami peningkatan sebesar $17 \%$ atau sebanyak 175,4 juta [10]. Dari jumlah tersebut terinci juga yang dilakukan pengguna internet, salah satunya adalah penggunaan media sosial. Bulan Januari 2020 pengguna aktif media sosial di Indonesia tercatat sebanyak 160 juta [10]. Terdapat beberapa platform media sosial yang tersedia, dan YouTube menjadi yang paling banyak diakses oleh pengguna internet di Indonesia yaitu sebesar 88\% [10]. Sehingga dengan demikian tidak salah Kementerian Agama Kab. Sleman dalam membuat kebijakan untuk menggunakan YouTube bagi penyuluh Agama Islam.

Kementerian Agama Kab. Sleman mempunyai sekitar 115 orang penyuluh Agama Islam yang bertugas untuk memberikan penyuluhan tentang Agama Islam kepada warga khususnya di lingkungan Kab. Sleman. Jumlah tersebut terbagi menjadi $30 \%$ orang penyuluh Agama Islam dengan status PNS dan $70 \%$ orang penyuluh Agama Islam dengan status Non-PNS. Sekitar 30\% penyuluh agama umurnya di atas 40 tahun, sisanya di bawah 40 tahun.

Penyuluh Agama Islam dengan umur di atas 40 tahun ini memiliki pengalaman yang sangat minimal dalam hal penggunaan teknologi seperti YouTube. Meskipun jumlahnya hanya berkisar di 30\% dari total penyuluh Agama Islam di Kabupaten Sleman, para penyuluh ini memiliki potensi jumlah pengikut dan jangkauan yang lebih luas karena telah melakukan penyuluhan lebih lama dibandingkan kelompok lainnya. Oleh sebab itu, perlu diadakan kegiatan pelatihan pemanfaatan media sosial YouTube untuk meningkatkan keterampilan para penyuluh Agama Islam di lingkungan Kementerian Agama Kab. Sleman untuk mendukung tugasnya dalam memberikan penyuluhan tentang Agama Islam kepada masyarakat.

\section{METODE}

\subsection{Analisis Akar Masalah}

Sebelum melaksanakan pelatihan penggunaan YouTube untuk dakwah, penulis terlebih dahulu menganalisis situasi terkini menggunakan metode Fish Bone Analysis. Analisis ini bertujuan untuk melihat akar permasalahan sehingga program yang diselenggarakan dapat tepat sasaran dana benar-benar bermanfaat bagi peserta. Adapun diagram Fish Bone hasil analisis dapat dilihat pada Gambar 1.

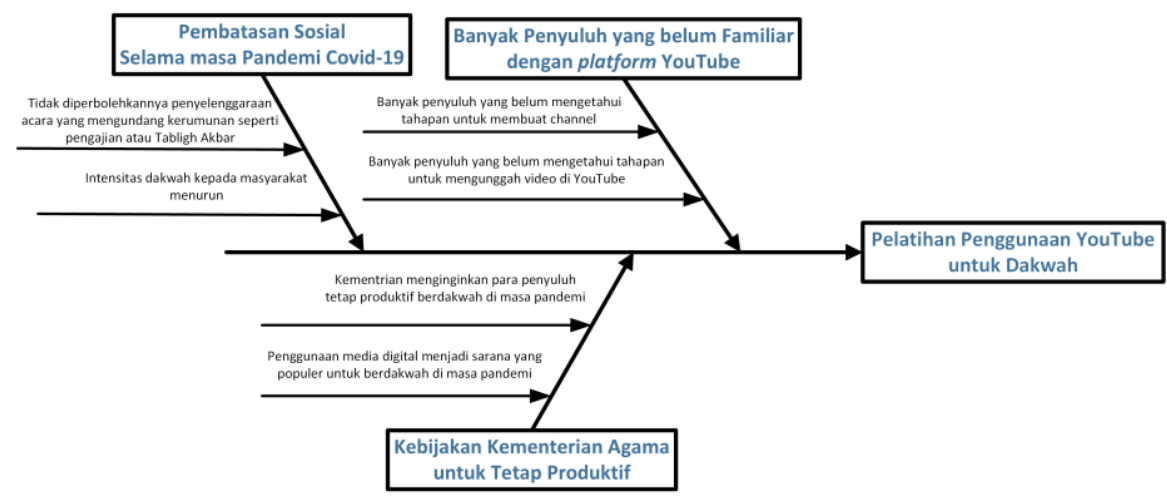

Gambar 1. Diagram Analisis Akar Masalah

Berdasarkan gambar di atas, penulis menemukan ada 3 faktor utama sebagai akar permasalahan, yaitu adanya pembatasan sosial selama masa pandemi Covid-19, adanya kebijakan yang meminta para penyuluh 
agama untuk tetap produktif berdakwah selama di tengah masa pandemi Covid-19, dan belum familiar-nya para penyuluh dengan platform YouTube yang saat ini menjadi salah satu solusi untuk berdakwah di tengah masa pandemi Covid-19. Ketiga faktor inilah yang kemudian mendorong untuk diadakannya pelatihan kepada para penyuluh agama terkait pemanfaatan media YouTube untuk dakwah. Dengan adanya pelatihan ini diharapkan para penyuluh agama tetap produktif melakukan dakwah sesuai dengan kebjikan yang dikeluarkan kementerian tanpa menlanggar protokol kesehatan di tengah masa pandemi Covid-19.

\subsection{Langkah-langkah Penyelesaian Masalah}

Peserta pada pelatihan ini adalah penyuluh Agama Islam seluruh Kabupaten Sleman. Pelaksanaan pelatihan dilakukan sebanyak 3 kali pertemuan. Tiap pertemuan dilakukan selama 2 jam, satu jam pertama dijelaskan tentang aturan penggunaan YouTube yang ditentukan oleh Google, kemudian satu jam selanjutnya di praktikkan cara penggunaan YouTube mulai dari upload video, pemberian judul and deskripsi video, pemberian thumbnail sampai pengaturan video. Dijelaskan pula tentang aturan monetisasi YouTube.

Mekanisme pelaksanaan kegiatan pelatihan ini menggunakan empat metode. Pertama yaitu pembicara menyampaikan materi tentang YouTube secara langsung dengan menggunakan media LCD dan materi dalam bentuk PowerPoint, metode ini biasa disebut dengan metode ceramah [11]. Kedua, setelah pembicara menyampaikan materi, peserta diminta mempraktikkan upload video dan memberikan deskripsi di YouTube seperti yang sudah disampaikan oleh pembicara. Ketiga yaitu tanya jawab interaksi antara peserta dengan pembicara secara langsung dengan menanyakan langsung permasalahan yang dihadapi saat melaksanakan praktik upload video YouTube [11]. Keempat, pembicara menyebarkan kuesioner kepada peserta untuk mengetahui tingkat antusiasme peserta ketika sebelum dan sesudah mengikuti pelatihan penggunaan YouTube. Beberapa metode tersebut digunakan disesuaikan dengan isi materi, kondisi peserta, serta tingkat kemampuan peserta dalam memahami materi [11]. Tahapan kegiatan pelatihan seperti terlihat pada Gambar 2.

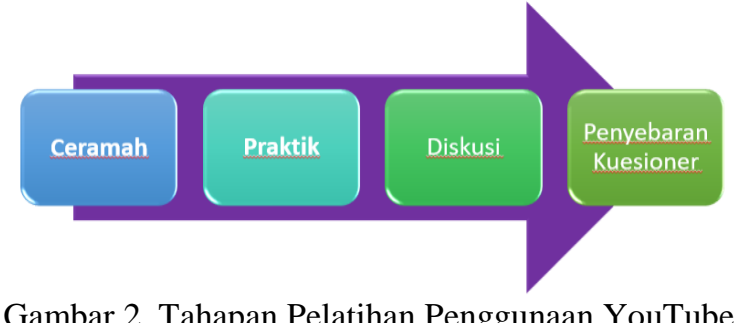

\section{HASIL DAN PEMBAHASAN}

Pelatihan penggunaan media sosial YouTube bagi penyuluh Agama Islam dilaksanakan selama tiga hari yaitu pada tanggal 16, 17, dan 23 November 2020 di Gedung pertemuan yang berlangsung pukul $13.30 \mathrm{~s} / \mathrm{d}$ 16.00 WIB. Hari pertama dihadiri oleh sekitar 35 orang peserta penyuluh Agama Islam di lingkungan Kab. Sleman. Masing-masing peserta membawa sendiri perangkat sendiri, yaitu laptop atau smartphone, sehingga peserta dapat mempraktikkan secara langsung apa yang disampaikan pembicara. Materi yang disampaikan juga tidak terlalu cepat dikarenakan hampir sebagian besar peserta masih belum familiar terhadap YouTube. Salah satu dokumentasi kegiatan pelatihan saat pembicara menyampaikan materi seperti terlihat pada Gambar 3. Setelah dilakukan penyampaian materi, selanjutnya peserta melakukan praktik, seperti terlihat pada Gambar 4.

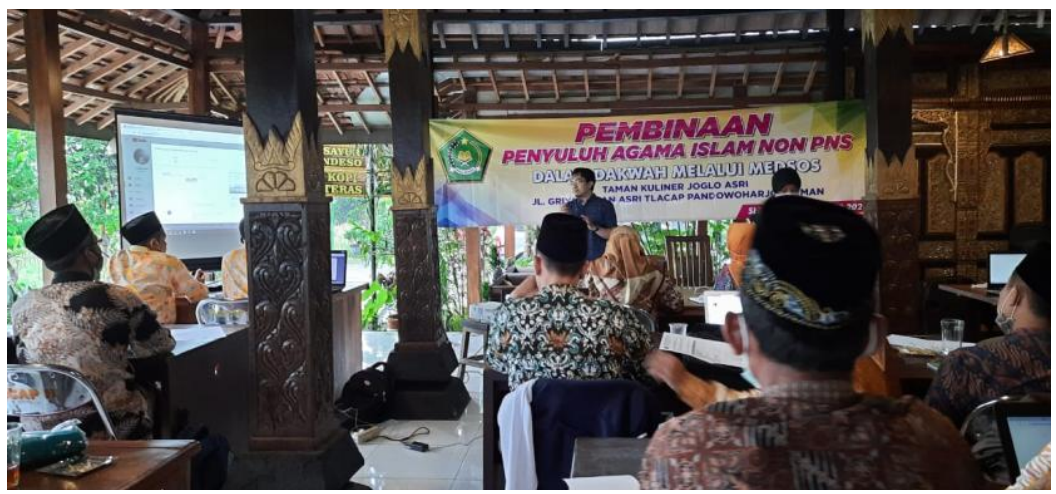

Gambar 3. Dokumentasi Kegiatan 


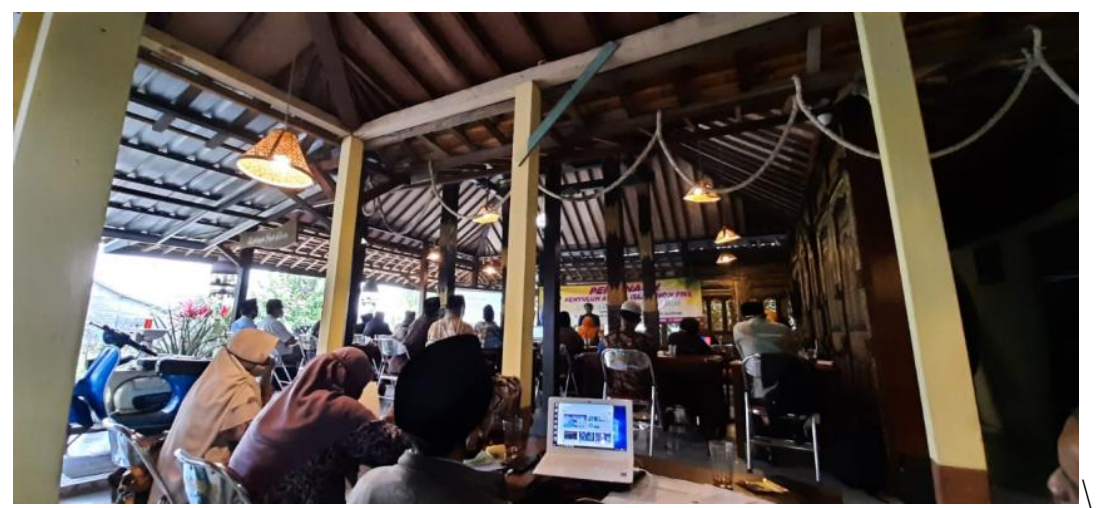

Gambar 4. Peserta Mempraktikkan Materi yang Sudah Disampaikan

Pelatihan penggunaan YouTube dimulai dari memastikan peserta memiliki email aktif dari Google, karena pada dasarnya YouTube adalah aplikasi platform milik Google sehingga untuk keperluan login-nya menggunakan Google Mail atau Gmail. Login YouTube menggunakan Gmail dimulai dari mengetik link YouTube.com pada address bar di browser. Selanjutnya pada bagian pojok kanan atas, klik simbol lingkaran, kemudian klik login, akan muncul tampilan login seperti pada Gambar 5.

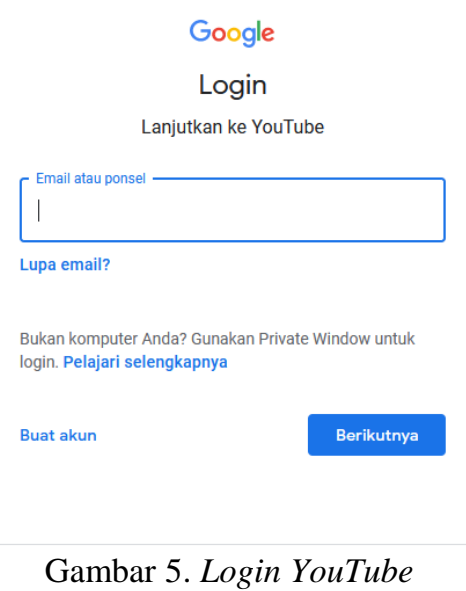

Setelah login, selanjutnya akan terjadi proses verifikasi akun Gmail yang akan digunakan sebagai akun YouTube. Akun gmail yang sudah diverifikasi sebagai akun YouTube selanjutnya disebut dengan Channel YouTube. Tampilan halaman home Channel YouTube seperti terlihat pada Gambar 5. Untuk melihat video yang di-upload bisa dilihat pada bagian pengelolaan video, untuk masuk ke pengelolaan video dengan cara klik button Kelola Video yang terdapat pada bagian kanan atas, seperti terlihat pada Gambar 6.
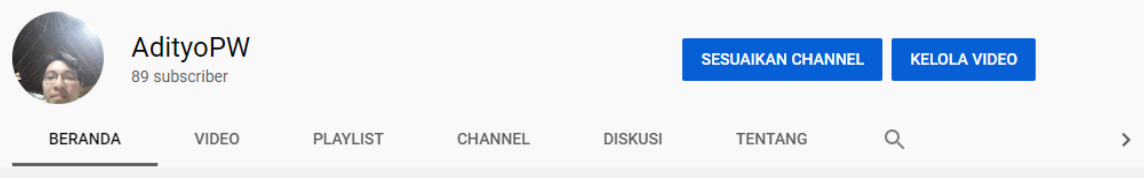

Gambar 6. Halaman Home Channel YouTube

YouTube memiliki 2 fasilitas yang disediakan untuk pengolahan video, yaitu Upload video dan Live streaming. Upload video adalah untuk video yang sudah berlangsung dan baru dipublikasikan, sedangkan Live streaming digunakan untuk broadcast video yang sedang berlangsung. Menu fasilitas tersebut seperti terlihat pada Gambar 7. 


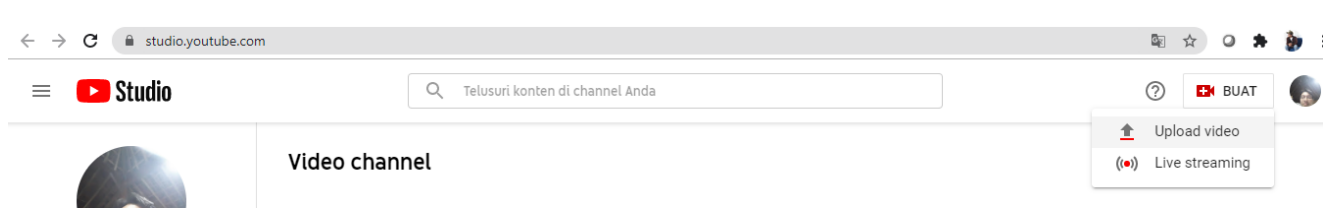

Gambar 7. Fasilitas Pengolahan Video pada YouTube

Materi pelatihan ini fokus kepada cara dan pengaturan upload video ke YouTube, sehingga diharapkan video yang di-upload banyak diakses oleh pengguna YouTube, muncul ke timeline pengguna, serta bisa muncul berdasarkan pencarian yang dilakukan oleh pengguna tersebut. Terdapat tiga langkah yang perlu dilakukan saat upload video, langkah-langkah tersebut terdiri dari detail, elemen video, dan visibilitas. Langkah-langkah upload video seperti terlihat pada Gambar 8.

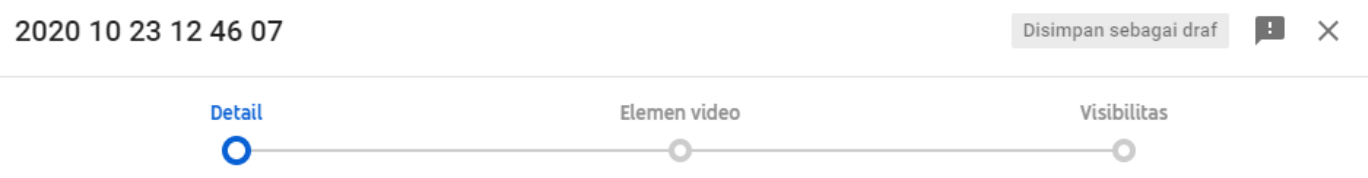

Gambar 8. Langkah-langkah Upload Video

Pengisian detail video berisi semacam identitas utama video yang di-upload, yaitu berisi judul video, dan deskripsi video. Yotube memiliki algoritma yang bisa mengetahui persamaan antara video yang di-upload dengan judul video, dan deskripsi video yang dituliskan [12]. Sehingga agar video bisa dilihat oleh banyak pengguna, pastikan video, judul dan deskripsi video harus singkron. Pengisian judul dan deskripsi judul seperti terlihat pada Gambar 9.

\section{Detail}

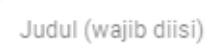

Gambar 9. Pengisian Judul Video dan Deskripsi Video.

Selain pengisian judul dan deskripsi, selanjutnya pengisian thumbnail video atau bisa disebut juga dengan cover video yang tampil/terlihat pada halaman YouTube. Selain thumbnail, juga ada pengelompokkan video jika video yang di-upload lebih dari satu dan masih sama kontennya. Pengisian thumbnail dan playlist seperti terlihat pada Gambar 10. 


\section{Thumbnail}

Pilih atau upload gambar yang menunjukkan isi video Anda. Thumbnail yang bagus akan

tampil menonjol dan menarik perhatian penonton. Pelajari lebih lanjut

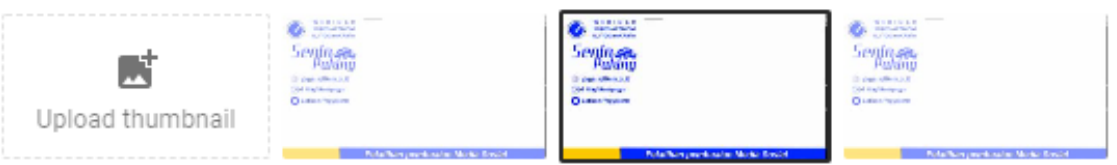

Playlist

Tambahkan video Anda ke dalam satu atau beberapa playlist. Playlist dapat membantu penonton menemukan konten Anda lebih cepat. Pelajari lebih lanjut

Playlist
Pilih

\section{Gambar 10. Pengisian Thumbnail dan Playlist}

Agar video masuk ke dalam hasil pencarian pengguna YouTube, perlu diisikan tag yang berguna untuk membantu penonton menemukan video yang di-upload. Gambar pengisian tag seperti terlihat pada Gambar 11.

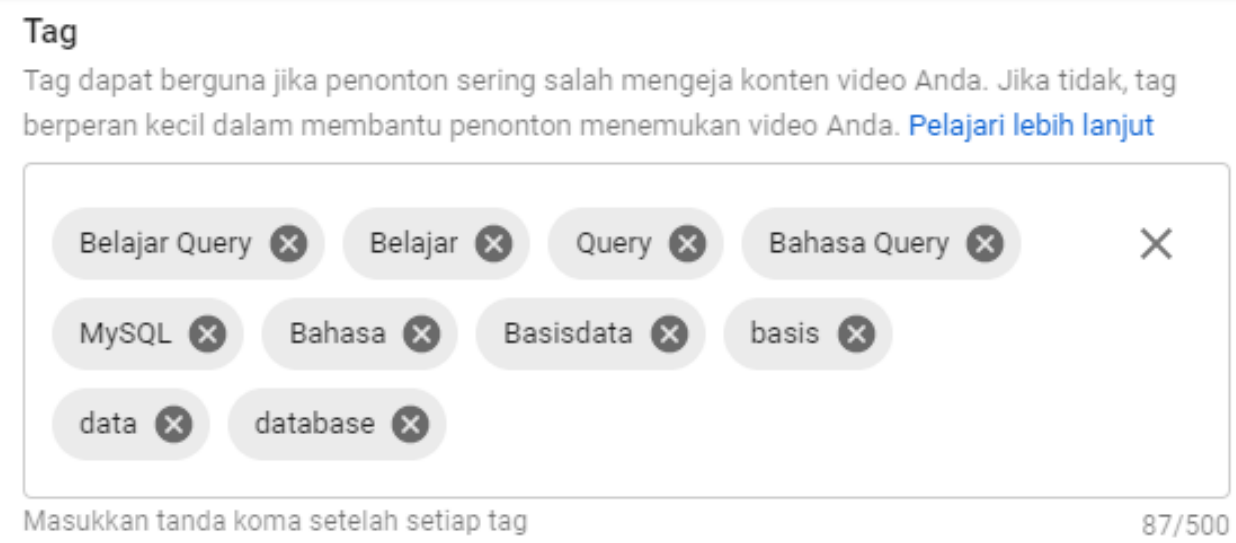

Gambar 11. Pengisian Tag

Selanjutnya, pengisian subtitel yang digunakan jika bahasa pada video tersebut berbeda dengan bahasa pengantar penonton. Pengisian subtitel ini bersifat opsional sehingga bisa diisi dan juga bisa juga tidak diisi. Selain itu juga pengisian tanggal perekaman video dan lokasi perekaman video. Seperti terlihat pada Gambar 12 .

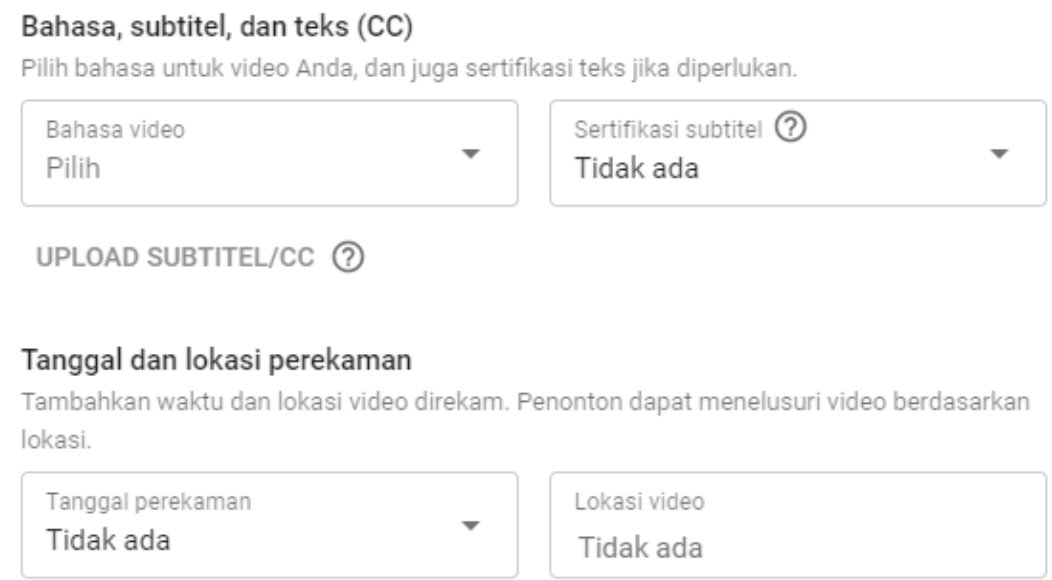

Gambar 12. Pengisian Subtitel dan Tanggal Perekaman Video 
Kemudian pengisian lisensi dan distribusi dari YouTube dan pemilihan Kategori. Pengisian kategori dilakukan untuk memetakan jenis video yang di-upload, sehingga pada saat penonton mencari video bisa sesuai dengan kategorinya. Pengisian Lisensi dan Kategori seperti terlihat pada Gambar 13.

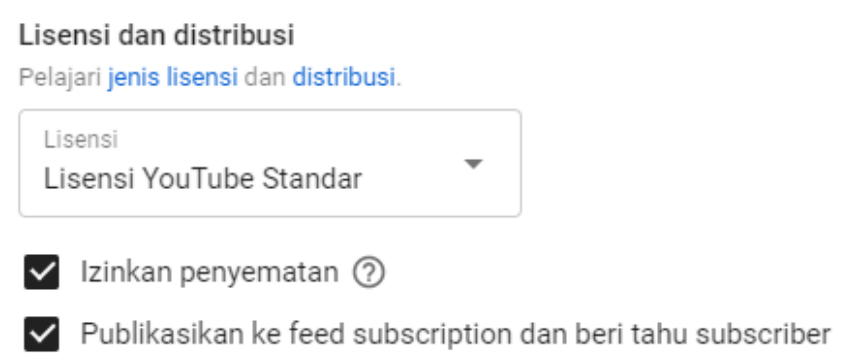

Kategori

Tambahkan video Anda ke sebuah kategori untuk memudahkan penonton menemukannya

Sains \& Teknologi

Gambar 13. Pengisian Lisensi YouTube dan Kategori

Langkah terakhir dari pengisian detail video di YouTube adalah pengaturan visibilitas komentar dan rating. Kolom komentar pada video bisa di aktifkan atau di nonaktifkan. Komentar tersebut juga bisa dilakukan filtering oleh admin atau pemilik channel. Pengaturan visibilitas komentar dan rating seperti terlihat pada Gambar 14.

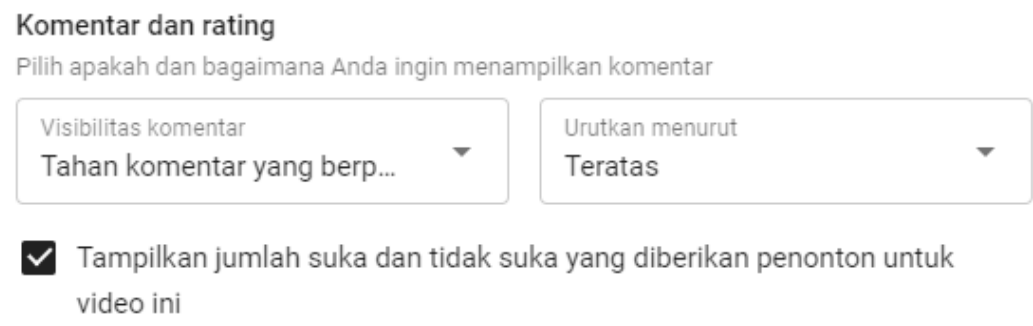

Gambar 14. Pengaturan Visibilitas Komentar

Langkah kedua yang perlu dilakukan saat upload video adalah pengaturan elemen video menambahkan kartu. Pengaturan ini berfungsi agar penonton lebih mudah melihat koleksi video yang dimiliki. Selain itu, bisa membuat penonton tidak cepat pergi dari saluran yang dikelola, karena video-video yang ada di koleksi akan terus dimunculkan [13]. Pengaturan penambahan kartu seperti terlihat pada Gambar 15.

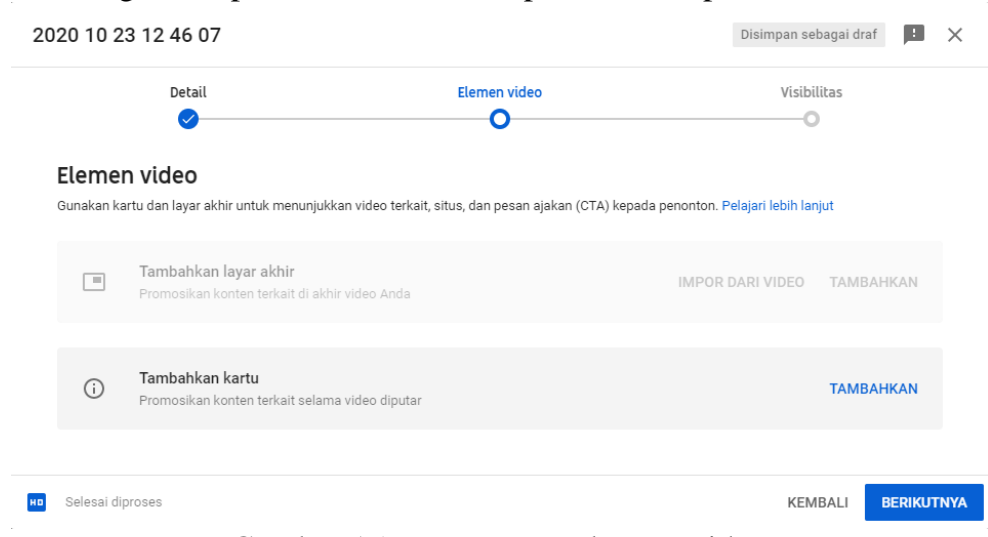

Gambar 15. Pengaturan Elemen Video 
Terakhir, pengaturan video yang harus dilakukan adalah visibilitas video yang terdiri dari Pribadi yang berarti tidak bisa dilihat oleh penonton umum, Tidak Publik yang berarti hanya orang tertentu yang bisa lihat video, dan Publik yang artinya bisa dilihat oleh penonton umum. Setelah di klik simpan, selanjtunya video akan tersimpan di home YouTube. Pengaturan visibilitas seperti terlihat pada Gambar 16.

\section{Visibilitas}

Pilih waktu publikasi dan siapa saja yang dapat melihat video Anda

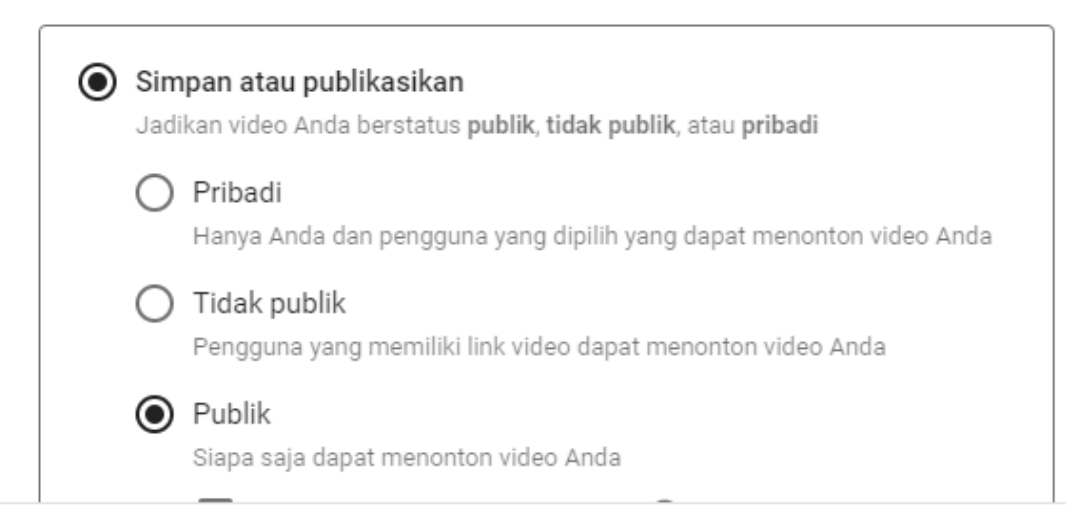

Gambar 16. Pengaturan Visibilitas Video

Selain memberikan pelatihan, penulis juga mengukur antusiasme peserta pada saat pelatihan. Pengukuran antusiasme dilihat dari 2 faktor yaitu tingkat kemudahan penggunaan YouTube dan dampak pelatihan penggunaan YouTube terhadap peserta untuk kegiatan penyuluhan Agama Islam. Pengukuran dilakukan menggunakan kuesioner yang dibagikan setelah pelatihan selesai dilaksanakan. Dari total peserta yang hadir pada saat pelatihan, terhitung 47 peserta yang mengisi kuesioner ini secara lengkap. Adapun hasil kuesioner pengukuran antusiasme ini dapat dilihat pada Tabel 1 dan Tabel 2.

Tabel 1. Hasil Kuesioner Tingkat Kemudahan Penggunaan YouTube

\begin{tabular}{clcc}
\hline No. & \multicolumn{1}{c}{ Variabel } & Ya & Tidak \\
\hline 1 & YouTube mudah digunakan & 43 & 4 \\
2 & YouTube menyenangkan untuk digunakan & 44 & 3 \\
3 & Menggunakan Youtube adalah ide yang bagus & 43 & 4 \\
4 & Youtube mudah dimengerti & 40 & 7 \\
5 & Youtube tidak sulit untuk dipelajari & 39 & 8 \\
\hline
\end{tabular}

Tabel 2. Hasil Kuesioner Dampak Pelatihan terhadap Peserta

\begin{tabular}{clcc}
\hline No. & \multicolumn{1}{c}{ Variabel } & Ya & Tidak \\
\hline 1 & $\begin{array}{l}\text { Saya berminat untuk meningkatkan penggunaan Youtube di } \\
\text { masa depan }\end{array}$ & 43 & 4 \\
2 & $\begin{array}{l}\text { Saya berminat menggunakan Youtube untuk melakukan } \\
\text { penyuluhan agama secara online }\end{array}$ & 43 & 4 \\
3 & Youtube meningkatkan kinerja saya & 40 & 7 \\
4 & Youtube membuat saya fleksibel & 40 & 7 \\
5 & Youtube bermanfaat bagi saya dan jamaah saya & 39 & 8 \\
\hline
\end{tabular}

Tabel 1 menunjukkan hasil kuesioner untuk mengukur tingkat kemudahan penggunaan YouTube bagi penyuluh Agama Islam. Sedangkan Tabel 2 menunjukkan hasil kuesioner pengukuran dampak pelatihan YouTube terhadap peserta untuk kegiatan penyuluhan Agama Islam. Kolom variabel pada Tabel 1 dan Tabel 2 menunjukan variabel yang ditanyakan pada masing-masing kuesioner. Berdasarkan Tabel 1 secara keseluruhan, 88.94\% peserta yang mengisi kuesioner merasa YouTube menjadi mudah digunakan setelah mengikuti pelatihan. Hasil senada juga dapat ditemukan di Tabel 2 yang menunjukkan $87.23 \%$ peserta merasakan manfaat dari pelatihan yang diikuti dan antusias untuk menggunakan media YouTube selama masa pandemi Covid-19 dalam rangka penyuluhan Agama Islam. 


\section{KESIMPULAN}

Setelah dilakukan kegiatan pelatihan ini, diperoleh kesimpulan bahwa penyelenggaraan pelatihan ini menambah keterampilan para penyuluh Agama Islam di lingkungan Kab. Sleman dalam menggunakan teknologi media sosial, dalam hal ini adalah YouTube. Hal ini diperkuat dengan hasil kuesioner yang menunjukkan lebih dari $85 \%$ peserta merasa YouTube mudah digunakan dan antusias untuk menjadikan YouTube sebagai media penyuluh agama selama masa pandemic Covid-19. Dengan demikian penyelenggaraan pelatihan ini membuat penyuluh agama tetap dapat melakukan penyuluhan mengenai Agama Islam di lingkungan sekitar, bahkan bisa diikuti oleh masyarakat dunia karena bisa diakses secara online. Video yang sudah di-upload, jika sudah memenuhi persyaratan bisa diajukan monetisasi, tentunya berdasarkan persyaratan yang sudah ditentukan oleh YouTube.

\section{DAFTAR PUSTAKA}

[1] N. Fitriyana, "God Spot dan Tatanan New Normal di Tengah Pandemi Covid-19," J. Ilmu Agama, vol. 21, no. 1, pp. 43-54, 2020, doi: https://doi.org/10.19109/jia.v21i1.6147.

[2] M. R. Rinaldi and R. Yuniasanti, "Kecemasan Pada Masyarakat Saat Masa Pandemi Covid-19 Di Indonesia," MBridge Press, vol. 1, no. 1, Yogyakarta, pp. 137-150, 2020.

[3] N. R. Yunus and A. Rezki, "Kebijakan Pemberlakuan Lock Down Sebagai Antisipasi Penyebaran Corona Virus Covid-19,” SALAM J. Sos. dan Budaya Syar-i, vol. 7, no. 3, pp. 227-238, 2020, doi: 10.15408/sjsbs.v7i3.15083.

[4] I. A. M. Darmayanti, "Pemanfaatan Media YouTube Berita Pendidikan dalam Pembelajaran Keterampilan Menyimak," in Prosiding Seminar Nasional V Bahasa, Sastra, dan Pengajarannya, 2018, pp. 2-3.

[5] R. P. Tutiasri, N. K. Laminto, and K. Nazri, "Pemanfaatan YouTube Sebagai Media Pembelajaran Bagi Mahasiswa di Tengah Pandemi Covid-19," Juurnal Komun. Masy. dan Keamanan, vol. 2, no. 2, pp. 1-15, 2020.

[6] M. Y. Kamhar and E. Lestari, "Pemanfaat Sosial Media YouTube Sebagai Media Pembelajaran Bahasa Indonesia Di Perguruan Tinggi," Intel. J. Ilmu Pendidik., vol. 1, no. 2, pp. 1-7, 2019.

[7] B. Pratiwi and K. P. Hapsari, "Analisis Kemampuan Berpikir Tingkat Tinggi Melalui Pemanfaatan YouTube Sebagai Media Pembelajaran Bahasa Indonesia,” J. Ilm. Sekol. Dasar, vol. 4, no. 2, p. 282, 2020, doi: 10.23887/jisd.v4i2.24238.

[8] A. F. Ramadhan and D. A. Zuliestiana, "Analisis Pemanfaatan YouTube Sebagai Social Media Marketing Go-Jek Dalam Mempengaruhi Minat Beli Dan Loyalitas Terhadap Brand,” J. Mitra Manaj., vol. 3, no. 5, pp. 273-285, 2019, [Online]. Available: http://e-jurnalmitramanajemen.com/index.php/jmm/article/view/125/69.

[9] S. Kemp, "Digital 2019: Indonesia," dateportal.com, 2019. https://datareportal.com/reports/digital-2019-indonesia (accessed Nov. 23, 2020).

[10] S. Kemp, "Digital 2020: Indonesia," dateportal.com, 2020. https://datareportal.com/reports/digital-2020-indonesia (accessed Nov. 18, 2020).

[11] R. Rianto and A. K. Wardana, "Pelatihan Microsoft Office Sebagai Upaya Pengembangan dan Peningkatan Kemampuan Penggunaan Aplikasi Pengolah Kata Dan Angka Bagi Guru PAUD Al Muthi'in Yogyakarta," KACANEGARA J. Pengabdi. pada Masy., vol. 2, no. 2, pp. 99-104, 2019, doi: 10.28989/kacanegara.v2i2.446.

[12] MLR, "Mengupas Tuntas Algoritma YouTube 2020," crafters, 2020. https://crafters.getcraft.com/idarticles/algoritma-YouTube-2020.

[13] L. Setiawan, "Cara Menggunakan Fitur Kartu dan Layar Akhir di YouTube,” inwepo.co, 2020. https://inwepo.co/cara-menggunakan-fitur-kartu-dan-layar-akhir-di-YouTube/. 
